\title{
UNIVERSAL AND PARTICULAR FEATURES OF LEGAL LANGUAGE IN HEIKKI E.S. MATTILA'S CONCEPTION OF COMPARATIVE LEGAL LINGUISTICS
}

\author{
by Marcus GALDIA \\ International University of Monaco \\ mgaldia@monaco.edu
}

Review of Heikki E.S. Mattila's Vertaileva oikeuslingvistiikka. Juridinen kielenkäyttö, lakimieslatina, kansainväliset oikeuskielet, 2nd updated edition, 2017, Helsinki: Alma Talent, pp. 702.

Professor Heikki E.S. Mattila became internationally known as a legal linguist mainly due to pioneering editions of his Comparative Legal Linguistics that are studied in the international academia in their English and French language versions (cf. Mattila 2012 and 2013). Meanwhile, the editions in English and French go back to the Finnish original of his book Vertaileva oikeuslingvistiikka that appeared in print for the first time 2002 in Helsinki. Over the years, Mattila expanded and updated his account of the legal language and refined the theoretical foundations of his conception of comparative legal linguistics. The author himself remarks that all versions of his Comparative Legal Linguistics bear witness to the development of one and the same work (cf. Mattila 2017: 


\section{Marcus GALDIA, Universal and particular features...}

xi). When the recent book is seen in this perspective, then it represents the fifth expanded and updated version of his conception.

The second Finnish edition appears now in print largely expanded and updated. The initial part has been reworded and reedited. In comparison with the international editions, its special topics include a detailed account of the development of Scandinavian legal languages in an own chapter C VI Pohjoismainen oikeuskieliyhteisö (Scandinavian legal-linguistic community). Next to it, legal Finnish is elucidated in the book on many places and in many respects. In the legal-linguistic research, Mattila's chapter on the Scandinavian legal-linguistic community and his numerous analyses of Finnish linguistic samples as well as the developments in Finland are particularly valuable both to legal linguists and to specialists in Scandinavian languages as updated research accounts in this area are rare (cf. Mattila 2005, Mattila/Piehl/Pajula 2010, Mattila 2010, Tyynilä 2010). Those existing concentrate as a rule upon one Scandinavian language. This approach contains the risk that commonalities in the Scandinavian development pass unmarked. Therefore, Mattila's chapter on Scandinavian legal languages balances many deficits in the research.

Mattila divides his book in four parts: A (General), B (Legal Language as Language for Special Purposes), C (Great Legal Languages), and D (Conclusions). Most of these chapters have been reviewed in numerous publications. In the edition discussed here they include updated references to many research materials that appeared recently in print. In addition, Mattila's views are regularly clarified in all chapters. Especially, the interplay between universal structural features and particularities of legal languages is very clearly demonstrated in the book. For Mattila's regular readers, the most interesting part of the book concerns Scandinavian languages. In part C entitled Great Legal Languages the chapter VI deals with the Scandinavian legal-linguistic community (pp. 253 - 292). The methodical matrix for the chapter is prepared in the paragraph on Scandinavian languages (pp. 46 - 47). In his preliminary remarks Mattila stresses the Scandinavian cooperation in the area of law that has long historical roots reaching beyond the institutionalized dialogue within the Nordic Council and the European Union (cf. also Ylikangas 1983 117-125, 164-180). In the main chapter on the Scandinavian legallinguistic community he shows how the modern, largely harmonized Scandinavian legal and legal-linguistic landscape emerged towards the background of terminological particularities that are present in 
Scandinavian legal languages to this day (cf. for instance Swedish laglott and Finnish lakiosa, Norwegian pliktdel and Danish tvangsarv for statutory share (p. 288). In the legal terminology of the European North the historical divide into two blocks comprising Denmark, Norway, and Island on the one side as well as Sweden and Finland on the other side is still visible (p. 253). As the political unification of the North was never fully achieved, the legal harmonization that dominates the developments in the legislation of Scandinavian countries did not lead to complete terminological uniformization. Due to socio-political and cultural commonalities the common heritage prevails however over legal-linguistic particularities. Meanwhile, when different Scandinavian languages are used in administrative contacts or academic conferences in Scandinavia terminological particularities may also lead to misunderstandings (p. 258). Overall, the chapter on Scandinavian legal languages makes plain the interrelationship of universals and particularities in the development of the legal language. This is due to the approach that is comparative, while other chapters include also contrastive elements in the analysis of linguistic samples. Also at this point the interdependence between comparative law and comparative legal linguistics in Mattila's conception becomes particularly transparent.

In Mattila's conception of comparative legal linguistics that I analysed more systematically in my Lectures on Legal Linguistics (Galdia 2017: 84 - 85) the most salient characteristic feature is the approach to legal language that oscillates between the analysis of its general structural patterns and particularities of legal languages such as English, French, German, and many others. The choice of the comparative approach paves the way towards generalization of data that refers to particular legal languages. The anchorage of the conception of comparative legal linguistics in comparative law enabled its reception in many works authored by legal comparatists (cf. Lundmark 2012, Husa 2015). This circumstance is not surprising because Mattila's conception of comparative legal linguistics was mainly structured around legalcomparative paradigms. In fact, comparative approaches in law are more productive than are purely contrastive approaches (for contrastive approaches in linguistics cf. Fisiak, J. et al. 1978: 9 - 19). When comparing, it is necessary to determine what is actually compared (e.g. linguistic structures or language use) and to determine the perspective upon the object of studies. One can compare terminology in the contrastive perspective to show terminological incongruences 


\section{Marcus GALDIA, Universal and particular features...}

(cf. Husa 2015: 72 who speaks about 'contradictive research interest' in this context) or to stress conceptual affinities or 'integrative research interest' in Husa's methodological taxonomy (cf. Husa 2015: 71). For comparative law, Jaakko Husa stressed also another difference that is relevant to the methodology of legal linguistics consisting in the choice between comparison and parallel description of legal phenomena. In the area of comparative law the researcher's interest determines the particular comparative method as there is no one method of legal comparison (cf. Husa 2015: 71). In Mattila's book comparative perspectives dominate over contrastive views mainly due to the underlying rigorous conception that he set up for describing particular legal languages.

There is also reason to acknowledge that this Journal is specifically mentioned by Mattila as being particularly relevant to legallinguistic research (p. 20). As many fundamental legal-linguistic achievements originate in Poland Mattila lists on p. 29 also the most important Polish classics of legal linguistics and legal theory. He mentions Tomasz Gizbert-Studnicki, Maria Teresa Lizisowa, Andrzej Malinowski, Kazimierz Opałek (1918 - 1995), Jerzy Pieńkos (1932 2003), Jerzy Wróblewski (1926 - 1990), Sławomira WronkowskaJaśkiewicz, and Zygmunt Ziembiński (1920 - 1996). Mattila also frequently points to works by Aleksandra Matulewska for reference, especially in matters regarding legal translatology. Overall, the Polish legal-linguistic research is particularly well represented in the book and regular reference is made there to works by: E. Betańska, P. Borek, A. Choduń, K. Gałuskina, J. Sycz, K. Gortych - Michalak, J. Grzybek, B. Hałas, A. Jopek - Bosiacka, K. Kredens, S. Goźdź -Roszkowski, M. Wasilewska, A. Niewiadomski, M. Pawelec, A. Mróz, J. Nowak Michalska, A.Pawłowska, A. Plisecka, E. Rusak, H. Sierocka, H Święczkowska, A. Stępkowski, I. Szczepankowska, A. Tarwacka, W. Wołodkiewicz, J. Krzynówek, M. Zabłocka, and B. Żmigrodzka. This regular reference to Polish legal-linguistic research in Mattila's book makes his generally high opinion of Polish contributions to the development of this area of knowledge particularly convincing.

Mattila's book is very well structured and thoroughly researched. My suggestions would concern two points: The subtitle of the second Finnish version stresses the use of the legal language, legal Latin and international languages following closely the subtitles of the English and the French editions. As the Finnish version includes Scandinavian languages and Finnish as a special ongoing topic, it might 
have been useful to mention this specific value of the Finnish edition in the subtitle of the second edition. I would also welcome a more pronounced last word of the author at the end of the final chapter on perspectives of the legal-linguistic research.

Professor Heikki E.S. Mattila achieved in the second edition of his Vertaileva oikeuslingvistiikka a synthesis of most important points in his analysis of the universal legal language and numerous particular legal languages that he researched. Readers of the newest version of the book will definitely benefit from his views that are expressed in a particularly clear and precise language.

\section{Bibliographical references}

Fisiak, Jacek, Lipińska - Grzegorek, Maria, Zabrocki, Tadeusz 1978 An Introductory English - Polish Contrastive Grammar. Warszawa: Państwowe Wydawnictwo Naukowe.

Galdia, Marcus 2017 Lectures on Legal Linguistics. Frankfurt a.M.: P. Lang.

Husa, Jaakko 2015 A New Introduction to Comparative Law. Oxford/Portland: Hart.

Lundmark, Thomas 2012 Charting the Divide between Common and Civil Law. Oxford: Oxford University Press.

Mattila, Heikki E.S. 2005 Språket och den nordiska rättsfamiljen, in: Tidskrift, utgiven av Juridiska Föreningen i Finland, vol. 161, pp. $43-57$.

Mattila, Heikki E.S., Piehl, Aino, Pajula, Sari (eds.) 2010 Oikeuskieli ja säädöstieto. Suomenkielinen lakikirja 250 vuotta. Rättsspråk och författningsinformation. Den finskspråkiga lagboken 250 år. Helsinki: Suomalainen Lakimiesyhdistys.

Mattila, Heikki E.S. 2010 Suomalaisen oikeuskielen ominaispiirteet, in: Mattila, H.E.S., Piehl, A., Pajula, S. (eds.) 2010 Oikeuskieli ja säädöstieto. Suomenkielinen lakikirja 250 vuotta. Rättsspråk och författningsinformation. Den finskspråkiga lagboken 250 år. Helsinki: Suomalainen Lakimiesyhdistys, pp. 181 - 213.

Mattila, Heikki E.S. 2012 Jurilinguistique comparée. Langage du droit, latin et langues modernes. Cowansville: Éditions Yvon Blais.

Mattila, Heikki E.S. 2013 Comparative Legal Linguistics. Language of Law, Latin and Modern Lingua Francas, 2nd ed. Farnham/Burlington: Ashgate. 
Marcus GALDIA, Universal and particular features...

Pajula, Paavo 1960 Suomalaisen lakikielen historia pääpiirteittäin. Porvoo: WSOY.

Tyynilä, Markku 2010 Suomen kielen nousu oikeuskieleksi, in: Mattila, H.E.S., Piehl, A., Pajula, S. (eds.) 2010 Oikeuskieli ja säädöstieto. Suomenkielinen lakikirja 250 vuotta. Rättsspråk och författningsinformation. Den finskspråkiga lagboken 250 år. Helsinki: Suomalainen Lakimiesyhdistys, pp. 131-146.

Ylikangas, Heikki 1983 Varför förändras rätten. Lag och rätt såsom en del av den historiska utvecklingen. Porvoo: WSOY. 